\title{
BMJ Global Health The importance of an integrating framework for achieving the Sustainable Development Goals: the example of health and well-being
}

\author{
Ana Raquel Nunes, ${ }^{1}$ Kelley Lee, ${ }^{2}$ Tim O'Riordan ${ }^{3}$
}

To cite: Nunes AR, Lee K, O'Riordan T. The importance of an integrating framework for achieving the Sustainable Development Goals: the example of health and well-being. BMJ Global Health 2016;1:e000068. doi:10.1136/bmjgh-2016000068

Received 20 April 2016 Revised 1 September 2016 Accepted 2 September 2016

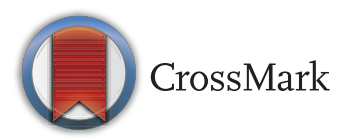

\footnotetext{
${ }^{1}$ Warwick Medical School, University of Warwick, Coventry, UK

${ }^{2}$ Faculty of Health Sciences, Simon Fraser University, Burnaby, British Columbia, Canada

${ }^{3}$ School of Environmental Sciences, University of East Anglia, Norwich, UK
}

Correspondence to Dr Ana Raquel Nunes; raquel.nunes@warwick.ac.uk

\section{ABSTRACT}

The 2030 Agenda for Sustainable Development came into force in January 2016 as the central United Nations (UN) platform for achieving 'integrated and indivisible' goals and targets across the three characteristic dimensions of sustainable development: the social, environmental and economic. We argue that, despite the UN adoption of the Sustainable Development Goals (SDGs), a framework for operationalising them in an integrated fashion is lacking. This article puts forth a framework for integrating health and well-being across the SDGs as both preconditions and outcomes of sustainable development. We present a rationale for this approach, and identify the challenges and opportunities for implementing and monitoring such a framework through a series of examples. We encourage other sectors to develop similar integrating frameworks for supporting a more coordinated approach for operationalising the 2030 Agenda for Sustainable Development.

\section{INTRODUCTION}

The 2030 Agenda for Sustainable Development, adopted by the United Nations (UN) General Assembly in September 2015 to replace the Millennium Development Goals (MDGs), is the central UN platform for achieving 'integrated and indivisible' Sustainable Development Goals (SDGs) across three dimensions: social, environmental and economic. The SDGs came into action in January 2016 aimed at offering a broad and inclusive framework for ending poverty worldwide in the next 15 years. ${ }^{1-4}$ It is widely recognised that successful achievement of this agenda, which is comprised of 17 SDGs and 169 targets, requires national, regional and local efforts across all sectors of society. For some, the SDGs are seen as an opportunity to bring together the development efforts of different sectors under a single agenda. ${ }^{15}$ Others are concerned that the 2030

\section{Key questions}

What is already known about this topic?

- After extensive negotiation, broad support for the 2030 Agenda for Sustainable Development was achieved, and the commitment to 17 Sustainable Development Goals (SDGs) and 169 targets came into effect in January 2016.

- Implementation of such a broad and diverse agenda, however, poses challenges for policy and practice at national, regional and local levels across all sectors of society.

- There is a particular need for integrating strategies and approaches for operationalising the SDGs in ways that emphasise their interdependence, and provide clear indicators and measures for their achievement.

\section{What are the new findings?}

- This paper proposes a framework for integrating health and well-being across the SDGs, extending over both health and non-health sectors.

- By locating health and well-being as both preconditions and outcomes of sustainable development, this approach leads to the identification of health-related SDGs and synergies between health and well-being, and other goals within the SDGs by sector.

- This, in turn, allows for particular objectives, and measures or indicators, for example, health issues and SDGs targets, to support the implementation of the 2030 Agenda for Sustainable Development.

Recommendations for policy

- The proposed health and well-being framework provides a model for more integrated implementation of the SDGs.

- The framework complements the Health In All Policies (HiAP) approach, by ensuring that health and well-being are cross-cutting and unifying themes.

- Importantly, the framework can also be used by other sectors to set particular objectives, measures or indicators which support an integrated approach to implementing the three dimensions of sustainable development underpinning the 2030 Agenda for Sustainable Development. 
Agenda for Sustainable Development is too broad and, as a result, difficult to measure and manage. ${ }^{6-8}$

SDG 3 of the SDGs is to 'ensure healthy lives and promote well-being for all at all ages'. ${ }^{4}$ Better health and well-being is not only viewed as a single goal for sustainable development, but is regarded as being essential for achieving all three pillars of sustainable development. ${ }^{9}$ Health, well-being and sustainable development are considered to be intrinsically connected, with health regarded as a precondition indicator, as well as an outcome of successful sustainable development. ${ }^{10}$ Within the health promotion literature, "sustainable development refers to the use of resources, direction of investments, the orientation of technological development, and institutional development in ways which ensure that the current development and use of resources do not compromise the health and well-being of future generations". 11 The challenge faced, therefore, is how to implement SDG 3 while, at the same time, supporting an integrated approach to the 2030 Agenda for Sustainable Development.

This paper begins by locating health and well-being as both preconditions and outcomes of sustainable development. We argue that, without 'good health and well-being for all', achieving the SDGs will be extremely problematic. $^{5}{ }^{12}$ At the same time, health and well-being are dependent on the achievement of other SDGs. Based on this dual relationship, we put forth a framework for integrating health and well-being across the SDGs, covering both health and non-health sectors. The framework identifies particular objectives, and measures or indicators for specific health issues and SDGs targets. We believe that the framework can be used by other sectors to support an integrated approach to implementing the three dimensions of sustainable development underpinning the 2030 Agenda for Sustainable Development.

\section{FROM MDGs TO SDGs}

The UN Secretary General Ban Ki-Moon calls the MDGs, signed in January 2000, 'the most successful antipoverty movement in history, ${ }^{13}$ by lifting more than one billion people out of extreme poverty, and making specific gains on targets such as reducing hunger, increasing female education and advancing environmental protection. At the same time, it is recognised that much work remains to be done to address persistent inequalities and uneven progress. ${ }^{14} 15$ There are also concerns that recent conflicts, growing extremism, unprecedented levels of migration, ${ }^{16}$ continued economic and financial volatility, and large-scale environmental changes are undermining some of the MDGs achievements. ${ }^{12} 1417$

In this context, high expectations are being placed on the SDGs to do more over the next 15 years. ${ }^{23}$ The new agenda departs from the MDGs in two important respects. First, the UN Secretary General's High-Level Panel on Sustainable Development highlights the importance of addressing the determinants of development and well-being within a 'universal framework' by which goals apply to every country and across all sectors of society. While the MDGs applied to developing countries, the SDGs are framed to address poverty alleviation in all countries. Second, the SDGs place sustainability at the heart of the development agenda, ${ }^{18}$ recognising the need to address the complex links between development and the environment. Based on lessons from the MDGs, the 2030 Agenda for Sustainable Development is seen as a unique opportunity to design new objectives, measures and indicators which are innovative and transformative. ${ }^{19}$ Of particular concern is the need to move away from a narrow set of quantitative goals and targets towards a broader range of more 'integrated and indivisible' goals and targets.

\section{HEALTH AND WELL-BEING WITHIN THE SDGs}

Health is defined by the World Health Organization (WHO) as 'a state of complete physical, mental and social well-being and not merely the absence of disease or infirmity'. ${ }^{20}$ Broadly speaking, 'health is a concern to all people, and is influenced by and as well contributing to policies across a wide range of sectors'. ${ }^{10}$ As health is extensively determined by economic, social and environmental conditions, we argue here that health is connected with topics such as poverty, gender equality, education, growth, among others, ${ }^{9}$ being thus crucial for the effective conditions for sustainable development. ${ }^{10}$

Health figured prominently in the MDGs. Three of the eight goals focused directly on health-related issues —reducing child mortality (MDG 4), improving maternal health (MDG 5) and combating HIV/AIDS, malaria and other diseases (MDG 6) -while three others were indirectly related to health-eradicating extreme poverty and hunger (MDG 1), ensuring environmental sustainability (MDG 7), and developing a global partnership for development (MDG 8). Under the SDGs, some argue that having only one health goal (SDG 3) among 17 goals is a step back from the MDGs. ${ }^{9}{ }^{21}$ Others, however, assert that giving such prominence to a single sector is out of step with the new emphasis on universality and sustainability. Thus, the UN asserted that the role of health should be reconsidered, including its relationship alongside the concept of 'well-being'. ${ }^{22}$ The Centers for Disease Control and Prevention (CDC) define well-being as 'a positive outcome that is meaningful for people and for many sectors of society, because it tells us that people perceive that their lives are going well. Good living conditions (eg, housing, employment) are fundamental to well-being,. ${ }^{23}$

Implementation of the 2030 Agenda for Sustainable Development, therefore, faces a need to reconcile strong support for better health and well-being, and the more integrated approach of sustainable development. The Rio Declaration on Environment and Development, signed by 170 countries in 1992, clearly and fully addresses the links between health and development. 
Principle 1 states that 'human beings are at the centre of concerns for sustainable development. They are entitled to a healthy and productive life in harmony with nature'. ${ }^{24}$ This link between health and sustainable development has been part of declarations that have followed. Despite this, and more recently regarding the new 2030 Agenda for Sustainable Development, it has been argued that the relationship between health and development should be further addressed ${ }^{22}$ so that health and well-being become central to sustainable development as argued here. In doing so, the UN and its agencies, ${ }^{22}$ in their 'Health in the post-2015 UN development agenda' report, have explicitly looked at the linkages between health and sustainable development through three different perspectives. Such relationship includes the idea that health can be a contributor, a beneficiary and a vehicle to measure success in achieving sustainable development. ${ }^{22} 25$

Some authors consider that SDG 3, to 'ensure healthy lives and promote well-being for all at all ages', fairly represents health and well-being within the SDGs as they stand. ${ }^{717}$ For example, the WHO asserts that the health and well-being goal is one that is very broad, allowing a multitude of issues lacking under the narrower MDGs to be addressed. These include mental health, environmental health and health security. ${ }^{17}$

Despite being set out as a separate goal, moreover, SDG 3 is recognised as critical for the achievement of other SDGs. Measures of health and well-being can be used to assess progress in the implementation of the SDGs. Conversely, most of the new generation of SDGs have a range of direct positive impacts on human health and well-being (eg, reductions in cardiovascular disease, lung cancer and stroke). There are also a range of health and well-being co-benefits of sustainable development (ie, poverty reduction, sustainable energy sources, safe drinking water, adequate sanitation, sustainable food production and distribution, urban planning). Consequently, the WHO argues that health and wellbeing are central measures of progress in achieving the SDGs as an overall strategy of the post-2015 agenda. ${ }^{26}$ For example, health and well-being are influenced by an array of factors (ie, determinants of health) such as social, environmental and economic factors that are intrinsically related to other SDGs. ${ }^{21}$ A series of indicators for sustainable cities, energy, water, sanitation and hygiene, and food production have been presented linking health and the SDGs. ${ }^{19}$ Overall, the WHO is confident that health and well-being remain central to the sustainable development framework, with SDG 3 as more integrated under this new agenda than the MDGs. ${ }^{17}$

\section{AN INTEGRATING HEALTH AND WELL-BEING FRAMEWORK}

Given recognition of the links between health and wellbeing, the SDGs, and sustainable development as a whole, there is need for a framework to guide more integrated action. This framework would focus on the
Table 1 Health-related SDG targets in the literature

\begin{tabular}{|c|c|}
\hline Health-related SDG targets & Sources \\
\hline $\begin{array}{l}2.2 ; 3.1-3.9 ; 3 . q-3 . d ; 5.2 ; 5.6 ; 6.1-6.3 ; 11.5 \\
13.1 ; 16.1 ; 16.9\end{array}$ & Murray $^{27}$ \\
\hline $2.2,6.1,6.2,6.3,11.2,11.5,12.4$ & $\begin{array}{l}\text { Le } \\
\text { Blanc }^{6}\end{array}$ \\
\hline $\begin{array}{l}\text { 1.3, } 1.5,2.1,2.2 \text {, all SDG } 3 \text { targets, } 4.5,4 . a, 5.2, \\
5.3,5.6,6.1,6.2,7.1,8.5,8.7,8.8,10.2,10.7 \\
\text { 11.1, } 11.2,11.5,11.7,11 . b, 12.4,13.3,16.2 \\
16.9,17.18\end{array}$ & $\mathrm{WHO}^{28}$ \\
\hline $\begin{array}{l}\text { 1.3, } 2.2,4.2,4 . a, 5.2,5.3,5.6,6.1,6.2,6.3 \text {, } \\
10.4,11.5,16.1,16.2,16.6,16.9,17.18\end{array}$ & $\mathrm{WHO}^{17}$ \\
\hline
\end{tabular}

SDG, Sustainable Development Goal.

interdependencies between goals, and encourage connections among different sectors. ${ }^{6}$ For example, the impacts of better health and well-being on poverty reduction and increased equality and, as a result, on achieving overall sustainable development, can be realised through more collaborative efforts between health and non-health sectors.

As a first step towards such a framework, we compile and compare lists of health-related SDG targets (see table 1). Murray ${ }^{27}$ identifies 23 health-related SDGs targets and Le Blanc ${ }^{6}$ includes seven targets related to health within the SDGs and asserts that health is linked with another eight goals. The $\mathrm{WHO}^{28}$ provides a more comprehensive list of health-related SDGs, which includes 27 targets plus all the health goal targets (17). In a recent report, the $\mathrm{WHO}^{29}$ considers a slightly different set of 17 targets as being health-related and linked to SDG 3. Table 1 shows that health is more embedded within the SDGs than previous approaches have identified. ${ }^{6272830}$

As a next step, and drawing on Wilkinson and Hulme, ${ }^{12}$ we can identify integrating links between goals. Table 2 sets out the synergies between health and well-being (SDG 3), and other SDGs, and the various sectors relevant to each. In this table, we acknowledge the cross-cutting role that health and well-being play, as preconditions, as well as outcomes, ${ }^{17} 22253132$ and vehicles to measure sustainable development. ${ }^{17}$ Additionally, we incorporate the 'Health in All Policies (HiAP)' strategy $^{25} 33$ to make links, between the SDGs, and health and well-being. Given that health, and health-related issues, fall within sectors other than health, ${ }^{25}$ incorporating health in all policies to support the SDGs has been suggested as a way to bring better integration and coherence to the new sustainable development agenda. ${ }^{34}$ In short, achieving SDG 3 is crucial to other SDGs, and achieving other SDGs is crucial to SDG 3. The integrating framework of table 2 provides a shared language and encourages more dialogue across sectors (table 2).

\section{IMPLEMENTING AND MONITORING THE HEALTH AND WELL-BEING FRAMEWORK}

Once synergies across the SDGs and sectors are identified (table 2), highlighting the interdependencies 


\begin{tabular}{|c|c|c|}
\hline SDGs & Synergies between health and well-being, and other goals & Sectors \\
\hline SDG 1-no poverty & $\begin{array}{l}\text { Poverty results in ill health as a consequence of lack of adequate nutrition, housing, } \\
\text { and access to safe drinking water and sanitation. Poor people struggle to educate } \\
\text { themselves and their children, are less able to find and remain in a job, and access } \\
\text { services that would alleviate poverty. Poor people are also made vulnerable to air } \\
\text { and water pollution and other hazards such as landslides, drought and flooding, all } \\
\text { of which carry physical and mental health dangers. Their poverty makes them } \\
\text { politically and economically unable to escape threats. } \\
\text { For achieving this goal it is vital to focus on better or improved health, reducing } \\
\text { inequalities and improve social protection and political efficacy. Bestowing health } \\
\text { and well-being assists in addressing the reduction of vulnerability. }\end{array}$ & $\begin{array}{l}\text { Economy; Employment; Education; Early life; Housing; } \\
\text { Health }\end{array}$ \\
\hline SDG 2-zero hunger & $\begin{array}{l}\text { Hunger and food scarcity result in malnutrition and ill health. } \\
\text { For achieving this goal it is crucial to incorporate the health benefits of sustainable } \\
\text { agriculture, food production and distribution. Having access to food improves human } \\
\text { health and enables better chances in life, including educational achievement (see } \\
\text { SDG 4). As such, patterns of development for food have bearing on health. }\end{array}$ & $\begin{array}{l}\text { Agriculture; Food; Environment; Land; Sustainability; } \\
\text { Security; Justice; Health }\end{array}$ \\
\hline $\begin{array}{l}\text { SDG 3-good health } \\
\text { and well-being }\end{array}$ & $\begin{array}{l}\text { Improved health for all countries, communities, families and individuals has } \\
\text { implications for achieving all SDGs. Investing in health is both a necessary and } \\
\text { effective way to achieve all the other goals. } \\
\text { Health is a major contributor to sustainable development, but much of the economic, } \\
\text { social and environmental determinants of health are outside the health sector so } \\
\text { there needs to be intersectoral coordinated action. On the other hand, better overall } \\
\text { health improves social and economic outcomes. } \\
\text { For achieving this goal it is imperative to increase the provision of and access to } \\
\text { health services, guarantee and expand UHC for reductions in mortality and morbidity } \\
\text { (eg, communicable and non-communicable diseases, mental health). }\end{array}$ & $\begin{array}{l}\text { Economy; Sustainability; Environment; Security; Justice; } \\
\text { Education; Infrastructure; Housing; Community services; } \\
\text { Transport; Early life; Planning; Land; Agriculture; Food; } \\
\text { Health }\end{array}$ \\
\hline $\begin{array}{l}\text { SDG } 4-\text {-quality } \\
\text { education }\end{array}$ & $\begin{array}{l}\text { Quality education impacts on the ability to get out of poverty, finding work, being } \\
\text { able to afford appropriate housing, access to drinking water and sanitation, } \\
\text { contributing to better health and well-being throughout the life span. On the other } \\
\text { hand, health is crucial for high levels of educational attainment for all men, women } \\
\text { and children, increasing opportunities for employment and living a meaningful life. } \\
\text { For achieving this goal it is important to understand the existing barriers and limits } \\
\text { for equal access to education (gender, race, ethnicity). }\end{array}$ & Education; Early life; Employment; Health \\
\hline $\begin{array}{l}\text { SDG } 5 \text {-gender } \\
\text { equality }\end{array}$ & $\begin{array}{l}\text { Gender equality promotes educational attainment, work opportunities and } \\
\text { empowerment to be an active citizen and seek better health. Equal access to quality } \\
\text { healthcare, sanitation and justice for better women's health as well as reductions of } \\
\text { violence and discrimination against women. } \\
\text { For achieving this goal it is essential to look at its links with education, employment } \\
\text { and health. }\end{array}$ & Education; Early life; Employment; Security; Justice; Health \\
\hline
\end{tabular}

\section{SDG 3-good health and well-being}

\section{SDG 4-quality}

\section{education}

SDG 5-gender

equality
Poverty results in ill health as a consequence of lack of adequate nutrition, housing, and access to safe drinking water and sanitation. Poor people struggle to educate cervices that and water pollution and other hazards such as landslides, drought and flooding, all

For achieving this goal it is vital to focus on better or improved health, reducing

Hunger and food scarcity result in malnutrition and ill health.

For achieving this goal it is crucial to incorporate the health benefits of sustainable implications for achieving all SDGs. Investing in health is both a necessary and

social and environmental determinants of health are outside the health sector so health improves social a

For achieving this goal it is imperative to increase the provision of and access to health services, guarantee and expand UHC for reductions in mortality and morbidity

Quality education impacts on the ability to get out of poverty, finding work, being able to afford appropriate housing, access to drinking water and sanitation, contributing to better health and well-being throughout the life span. On the other Foportunities for employment and living a meaningful life. . existing barriers and limits Gender equality promotes educational attainment, work opportunities and empowerment to be an active citizen and seek better health. Equal access to quality healthcare, sanitation and justice for better women's health as well as reductions of iscrimination against women.

eving this goal it is essential to and health. 


\section{SDGs \\ Synergies between health and well-being, and other goals}

SDG 6-clean water and sanitation

Access to safe drinking water, adequate sanitation and hygiene are essential to the health of individuals and communities, reduces pollution and the risk of communicable and non-communicable diseases (eg, diarrhoeal, vector-borne diseases) and improves housing quality and environmental conditions (eg, reduced water contamination).

For achieving this goal it is key to understand the links with poverty, urbanisation, education, water scarcity and water management, as well as hygiene for reducing the health risks of unsafe water and sanitation. As such, patterns of development for water have bearing on health.

SDG 7-affordable and Sustainable energy efforts (eg, clean, renewable energy) need to consider health clean energy benefits, alongside reductions in emissions and subsequently in air pollution, advances in urban planning and green spaces, infrastructure, transport and housing which create healthier living environments as well as employment opportunities. For achieving this goal it is imperative to ensure changes in the urbanisation process and energy demand for reductions in air pollution, and better access to cleaner energy with benefits for health (eg, reductions in cancer, stroke, COPD rates). As such, patterns of development for energy have bearing on health (eg, solar power and electricity and refrigeration).

SDG 8-decent work and economic growth

Economic sustainability can only be achieved with a healthy population. Healthy individuals are at the core of a healthy workforce. Improving work opportunities for individuals across sex and age increases and improves access to food, water, housing, services and justice.

For achieving this goal incentives should be given to the establishment of micro and small enterprises as well as microfinance. The role of women empowerment through microfinance depends on improved health, which is the route to education and independence.

\section{SDG 9-industry,}

innovation and

infrastructure

Health impacts should be taken into account when building resilient infrastructure

(eg, roads, transport, housing, building design) and developing new technologies aiming also at reducing health adverse environmental emissions.

For achieving this goal it is key to incorporate health and environmental well-being measures.

SDG 10 -reduced inequalities
Reducing disparities and inequalities in general and health inequalities in particular can result in reductions in morbidity and mortality. An equal society for all with distributive, redistributive, regulatory and constituent policies (ie, economic, education, social, fiscal, energy, housing, health) enhances access to education, services and work, among other.

For achieving this goal it is crucial to take into account the social and economic gradients of health in order to health and well-being.

\section{Sectors}

Environment; Sustainability; Security; Justice; Housing; Health
Environment; Sustainability; Infrastructure; Planning; Economy; Housing; Health
Economy; Employment; Security; Justice; Housing; Health

Infrastructure; Planning; Economy; Environment; Sustainability; Health

Economy; Education; Employment; Justice; Security; Health 


\section{SDGs}

SDG 11-sustainable cities and communities

SDG 12-responsible consumption and production
SDG 14-life below water

\section{Synergies between health and well-being, and other goals}

Improved housing quality, efficient public transport, safe roads, walking and cycling routes can be achieved to enhance the resilience of urban places where individuals live and work.

Policies that focus on improving planned urban growth, adequate housing, adequate infrastructures for energy, water and sanitation, access to green spaces in highly populated areas can improve among other objectives air quality, soil quality, water quality, waste management and human health (eg, communicable and non-communicable diseases).

For achieving this goal actions need to focus on planned urbanisation, safe drinking water and food security, health systems especially within the urban poor as ways for coordinating health and environmental well-being.

Reducing food waste, improving air, soil and water quality has beneficial impacts on human health and the environment. Sustainable agriculture and tourism, and the local jobs these provide can have a positive impact on the local economy and peoples' lives. This extends to healthy diets and to safe working conditions which are intrinsically part of genuine corporate well-being responsibility.

For achieving this goal there needs to be a focus on the preservation of natural resources/ecosystems and livelihoods of local people to improve the health of terrestrial and aquatic ecosystems (ie, green and blue spaces).

SDG 13-climate action Reduced vulnerability, enhanced resilience and improved adaptation can provide advances in the health of individuals, oceans, soil, etc. Integration of policies at different levels (ie, community, local, regional, national) is needed for improved education, empowerment and capacity building for all. Climate change carries all manner of additional health threats from new distributions of vectors.

For achieving this goal it is vital to emphasise the role education and environmental education have in influencing present and future culture of sustainability for achieving all the SDGs through bringing together individuals, communities, local businesses, local and national governments and public bodies to work together to allow sustainable development for all forever (eg, better health systems, health benefits from reduced human morbidity and mortality, poverty reduction, reduced water pollution and contamination, food security, sustainable energy and transport).

If the health of aquatic ecosystems and resources is considered, reduced pollution, protection of ecosystems and resources (ie, fish stocks) are stimulated, better planning is achieved. Resulting in local communities having a critical role in supporting sustainable use of water resources (ie, fisheries, tourism) with benefits for hunger and poverty reductions, human health, the environment and economy. For achieving this goal it is crucial to incorporate sustainable planning and conservation of aquatic ecosystems as well as sustainable use of its resources as

\section{Sectors}

Infrastructure; Housing; Community services; Transport; Planning; Justice; Culture; Land; Environment;

Sustainability; Health

Land; Agriculture; Environment; Sustainability; Economy; Health

Environment; Sustainability; Education; Early life; Planning; Security; Justice; Culture; Health

Planning; Culture; Land; Environment; Food; Sustainability; Economy; Employment; Health 
Table 2 Continued

SDGs Synergies between health and well-being, and other goals

they are vital components of the global ecosystem. There needs to be liaison of efforts for actions between marine and terrestrial ecosystems for sustainability.

\begin{tabular}{|c|c|c|}
\hline SDG 15-life on land & $\begin{array}{l}\text { Sustainable use of land and its resources can only be accomplished through policies } \\
\text { that take into account local communities and their livelihoods. Sustainable } \\
\text { livelihoods have positive benefits on the environment and the health of those } \\
\text { working the land. Sustainable terrestrial ecosystems are also source of food which } \\
\text { reduces hunger and improves human health. } \\
\text { For achieving this goal it is important to understand that protecting and promoting } \\
\text { terrestrial ecosystems (ie, soil) is hand-on-hand with marine ecosystems. Special } \\
\text { attention should be given to ensuring sustainable food production for a growing } \\
\text { population. }\end{array}$ & $\begin{array}{l}\text { Land; Culture; Environment; Agriculture; Food; } \\
\text { Sustainability; Planning; Economy; Employment; Health }\end{array}$ \\
\hline $\begin{array}{l}\text { SDG } 16 \text {-peace and } \\
\text { justice, strong } \\
\text { institutions }\end{array}$ & $\begin{array}{l}\text { Violence, crime and war affect those most vulnerable (eg, children, women and older } \\
\text { persons) and poor in society leading to increases in hunger, poverty, ill health. } \\
\text { Ensuring peace, reducing all forms of crime, violence, injuries and death rates has } \\
\text { positive impacts on the health and well-being of individuals and communities. } \\
\text { Implementing sustainable development policies and laws is critical to make societies } \\
\text { more just and secure for all. } \\
\text { For achieving this goal it is key to ensure individual and community security and } \\
\text { safety. }\end{array}$ & Security; Justice; Economy; Sustainability; Health \\
\hline $\begin{array}{l}\text { SDG } 17 \text {-partnerships } \\
\text { for the goals }\end{array}$ & $\begin{array}{l}\text { More equitable societies can be achieved through integration and coherence for } \\
\text { sustainable development. Monitoring and accountability of all other SDGs and } \\
\text { targets is needed to address and support improvements in all areas of society. } \\
\text { For achieving this goal it is crucial to involve multistakeholders (eg, governments, } \\
\text { private sector, civil society) at the local, national and global levels for more open and } \\
\text { participative decision-making processes for sustainable development. For the } \\
\text { purposes of this framework, health and well-being awareness should be embedded } \\
\text { in all aspects of goal evaluation and achievement. }\end{array}$ & $\begin{array}{l}\text { Economy; Sustainability; Environment; Security; Justice; } \\
\text { Education; Infrastructure; Housing; Community Services; } \\
\text { Transport; Early Life; Planning; Land; Agriculture; Food; } \\
\text { Health }\end{array}$ \\
\hline
\end{tabular}

COPD, chronic obstructive pulmonary disease; SDG,Sustainable Development Goal; UHC, universal health coverage. 
between health and well-being and other SDGs, there is a need to operationalise this approach through the identification of specific objectives, and measures or indicators, to monitor their achievement.

Table 3 sets out six examples of major health issues and how they relate to particular SDGs targets (eg, 1.1; 7.2) and current indicators for each target (eg, 1.1.1; 7.2.1). The six examples focused on the synergies between health and well-being, and other SDGs are advanced through specific objectives we propose to support intersectoral action. We argue that these actions seek to improve health and well-being as part of sustainable development. Actions in non-health sectors, aimed at reducing the disease burden arising from unsustainable practices, include infrastructure provision, economy, agriculture and food, in collaboration with the health sector. The improvement of social protection, health systems and services, the reduction of poverty and malnutrition, the access to sanitation, water and hygiene facilities, and the use of clean energy sources are further examples. Simultaneously, actions in the health sector can directly address health problems caused by broader determinants of health, such as the natural (eg, air, water and land pollution), working and built environments (housing quality, urban planning, sanitation and drinking water facilities, ventilation, toxic exposure).

Building on the current context of the SDGs, and framework of proposed indicators ${ }^{29}$ for the implementation of the 2030 Agenda for Sustainable Development, table 3 sets out examples of additional potential new indicators for guiding action, and assesses the extent to which progress is achieved towards the identified SDG targets and indicators. We acknowledge that the discussion about measurement of health and well-being has already started taking place, ${ }^{29}$ but argue that this is still at an early stage. The proposed global indicators, updated as of 4 March $2016,{ }^{29}$ are very pragmatic but, in some ways limited. Table 3 seeks to overcome the specificity of the SDGs by illustrating how it is possible to identify synergies among them, their targets and indicators with current health and well-being concerns (eg, malnutrition, respiratory diseases, obesity). By doing this, we argue that, despite the considerations above, it is possible to reconcile the tensions between a more focused health and well-being framework to the SDGs, and a wider integrated approach that considers the interdependences among goals, targets and indicators across the sweep of sustainable development.

These potential new indicators (table 3), specifically encourage connections between health and non-health sectors within the sustainable development agenda. In this way, an integrated approach is created which provides opportunities for more coherent and coordinated action across all sectors. For example, a focus on human rights, equity and basic cultural freedoms is included as affecting health-related sustainable development outcomes. We further comment on the extent to which current global indicators ${ }^{29}$ to be measured to assess the progress of the sustainable development agenda are too broad and unfocused. We contend that they need to be more specific and tailored so as to address all connected development topics. One of many of these examples is indicator 11.2.1 which can be linked with four of the six examples presented in table 3 (ie, respiratory diseases, lung cancer, overweight and obesity, road traffic accidents). Indicator 11.2.1 comprises the proportion of population that has convenient access to public transport, by sex, age and persons with disabilities', ${ }^{29}$ where it is not clear what convenient access means in practice for it to be consistently measured across countries. Indicator 11.2.1 exemplifies one of the ways in which other indicators need expanding, need to be more comprehensive and need to be more efficient in order to support and galvanise the success of the SDGs through the implementation, monitoring and review of a high-quality, more complete and exhaustive set of potential new indicators for achieving sustainable development, such as the ones suggested in table 3 .

As the UN specialised agency for health, and 'directing and coordinating authority on international health work', the WHO has a lead role to play in helping to identify and implement an integrating framework for health and well-being for the SDGs. The WHO can serve as the link agency, between SDG 3 and other SDGs, by ensuring all member states fulfil their commitment to the 2030 Sustainable Development Agenda. The WHO can locate this role by locating it within the implementation and monitoring of a health in all policies Agenda for Sustainable Development, providing strong technical support to developing clear objectives, measures or indicators, for national, regional and global action.

However, given the intersectoral nature of the sustainable development agenda, and the many other actors now contributing to global health cooperation, the WHO alone cannot take forward the health and sustainable development agenda. The integrated framework to the SDGs put forth here requires closer cooperation across the multiplicity of actors that now populate the global health governance landscape. Indeed, such an approach to the SDGs may provide an opportunity to build networks among these diverse actors, bringing together their efforts to work across health issues and sectors. For example, within the health sector, tackling diarrhoeal diseases might bring together the technical expertise of the WHO on disease prevention, control and treatment, financing of infrastructure by the World Bank, local capacity building efforts of the US CDC, research funding for innovative solutions by the Gates Foundation, and community level initiatives by the Global Public-Private Partnership for Handwashing; and in the non-health sector, the development of innovative solutions to water, sanitation and hygiene needs for children of the UN Children's Fund (UNICEF), advocacy by the UN Development Programme (UNDP) for access to clean water and sanitation as a basic right. This network of 
Table 3 Examples of health issues, SDGs targets and current indicators for each target, our proposed objectives and potential new indicators

\section{Health issue}

Respiratory $\quad 1.1(1.1 .1) ; 1.2(1.2 .1 ; 1.2 .2) ; 1.3(1.3 .1) ; 1.4(1.4 .1)$

diseases

2.1 (2.1.1; 2.1.2); $2.2(2.2 .1 ; 2.2 .2) ; 3.3$ (3.3.1); 3.4

(3.4.1); 3.8 (3.8.1; 3.8.2); 3.9 (3.9.1); 3.a (3.a.1); 7.1

(7.1.1; 7.1.2); 7.2 (7.2.1); 7.a (7.a.1); 7.b (7.b.1); 11.1

(11.1.1); 11.2 (11.2.1); 11.6 (11.6.2); 12.c (12.c.1)

$13.1(13.1 .1 ; 13.1 .2) ; 13.2(13.2 .1) ; 13.3(13.3 .1$

13.3.2)

\section{Diarrhoeal}

diseases

1.1 (1.1.1); 1.2 (1.2.1; 1.2.2); 1.3 (1.3.1); 1.4 (1.4.1); 3.2 (3.2.1; 3.2.2); 3.3 ; 3.8 (3.8.1; 3.8.2); 3.9 (3.9.2; 3.9.3); 6.1 (6.1.1); 6.2 (6.2.1); 6.3 (6.3.1; 6.3.2); 11.1 (11.1.1); 11.6 (11.6.1); 12.4 (12.4.1; 12.4.2); 13.1 (13.1.1; 13.1.2); 13.2 (13.2.1); 13.3 (13.3.1; 13.3.2)
SDGs targets and current indicators for each

\section{Proposed objectives (intersectoral} actions)

To improve access to social protection and health systems and services

To reduce malnutrition

To improve access to clean energy sources (eg, renewable) to reduce outdoor and indoor air pollution (eg, coal, biomass, radon)

To reduce exposure to smoke from cooking and heating with coal and biomass To improve access to sustainable, clean energy

To reduce overcrowding

To reduce smoking and passive smoking prevalence

To improve access to social protection and health systems and services

To improve sanitation infrastructure and facilities

To promote personal hygiene and behaviour change

To improve water infrastructure and drinking water quality

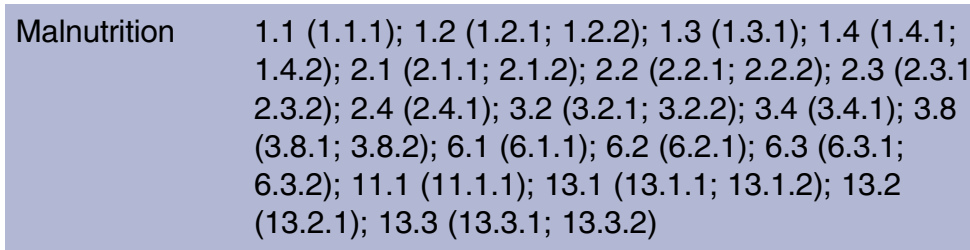

To improve access to social protection and health systems and services

To reduce poverty and hunger

To improve food intake and access to high nutritional food

To promote sustainable food production and distribution

To improve access to land

To improve sanitation, quality of drinking water and personal hygiene

To mitigate and adapt to climate change to improve food security

\section{Examples of potential new indicators}

Proportion of population who have access to socia protection and health services-for example, time/ kilometres from home, and social support for travel/ access

Proportion of population with access to adequate food and energy intake

Proportion of households with access to sustainable and clean energy sources (eg, renewables) Reduce the exposure to outdoor and indoor air pollution (eg, coal, biomass, radon) and related respiratory diseases, and deaths by $\mathrm{x} \%$.

Number of people living in each house and bedroom Reduce exposure to smoking and passive smoking, and related deaths by $\mathrm{x} \%$

Proportion of population who have access to social protection and health services-for example, time/ kilometres from home, and social support for travel/ access

Proportion of households with access to reliable sanitation infrastructure and facilities

Proportion of households with access to hand and body-washing facilities

Proportion of households with access to clean drinking water facilities

Proportion of population who have access to social protection and health services-for example, time/ kilometres from home and social support for travel/ access

Proportion of population with malnutrition by age

group

Proportion of people with access to adequate food and energy intake

Proportion of rural population with access to cultivable land

Proportion of households with access to sanitation, hand and body-washing and drinking water facilities Number of countries taking active actions and

Continued 


\begin{tabular}{|c|c|c|c|}
\hline Health issue & $\begin{array}{l}\text { SDGs targets and current indicators for each } \\
\text { target }^{29}\end{array}$ & $\begin{array}{l}\text { Proposed objectives (intersectoral } \\
\text { actions) }\end{array}$ & Examples of potential new indicators \\
\hline & & & $\begin{array}{l}\text { implementing measures to improve food security by } \\
\text { mitigating and adapting to climate change }\end{array}$ \\
\hline Lung cancer & $\begin{array}{l}1.1(1.1 .1) ; 1.2(1.2 .1 ; 1.2 .2) ; 1.3 \text { (1.3.1); } 1.4 \text { (1.4.1); } \\
3.4 \text { (3.4.1); 3.8 (3.8.1; 3.8.2); 3.9 (3.9.1); 3.a (3.a.1); } \\
\text { 7.1 (7.1.1; 7.1.2); 7.2 (7.2.1); 7.a (7.a.1); 7.b (7.b.1); } \\
\text { 11.1 (11.1.1); } 11.2(11.2 .1) ; 11.6 \text { (11.6.1); } 12.4 \\
\text { (12.4.1); 12.c (12.c.1) }\end{array}$ & $\begin{array}{l}\text { To improve access to social protection and } \\
\text { health systems and services } \\
\text { To reduce smoking and passive smoking } \\
\text { prevalence } \\
\text { To improve access to clean energy sources } \\
\text { (eg, renewable) to reduce outdoor and } \\
\text { indoor air pollution (eg, coal, biomass, } \\
\text { radon) }\end{array}$ & $\begin{array}{l}\text { Proportion of population who have access to social } \\
\text { protection and health services-for example, time/ } \\
\text { kilometres from home and social support for travel/ } \\
\text { access } \\
\text { Reduce the exposure to smoking and passive } \\
\text { smoking, and related deaths by } \mathrm{x} \% \\
\text { Reduce the exposure to outdoor and indoor } \\
\text { pollution (eg, coal, biomass, radon) and related } \\
\text { deaths by } \mathrm{x} \%\end{array}$ \\
\hline $\begin{array}{l}\text { Overweight } \\
\text { and obesity }\end{array}$ & $\begin{array}{l}1.1(1.1 .1) ; 1.2(1.2 .1 ; 1.2 .2) ; 1.3(1.3 .1) ; 1.4(1.4 .1) \\
3.4(3.4 .1) ; 3.8(3.8 .1 ; 3.8 .2) ; 11.2(11.2 .1) ; 11.7 \\
(11.7 .1)\end{array}$ & $\begin{array}{l}\text { To improve access to social protection and } \\
\text { health systems and services } \\
\text { To reduce the intake to high nutritional food } \\
\text { To reduce sedentary lifestyles and promote } \\
\text { physical activity } \\
\text { To promote walking, cycling, use of public } \\
\text { transport } \\
\text { To improve urban planning, access and use } \\
\text { of public green and blue spaces } \\
\text { To implement public policies that support } \\
\text { healthy diets }\end{array}$ & $\begin{array}{l}\text { Proportion of population who have access to social } \\
\text { protection and health services-for example, time/ } \\
\text { kilometres from home, and social support for travel/ } \\
\text { access } \\
\text { Proportion of population overweight and obese, by } \\
\text { age group } \\
\text { Proportion of population with diabetes type } 2 \\
\text { Mortality and morbidity attributed to overweight and } \\
\text { obesity } \\
\text { Proportion of population travelling by public } \\
\text { transport, cycling and walking, by kilometres/number } \\
\text { of journeys } \\
\text { Reduce the exposure to outdoor pollution, related } \\
\text { diseases and deaths by } \mathrm{x} \%\end{array}$ \\
\hline $\begin{array}{l}\text { Road traffic } \\
\text { accidents }\end{array}$ & $\begin{array}{l}1.1 ; 1.2 ; 1.3 ; 1.4 ; 3.5(3.5 .1 ; 3.5 .2) ; 3.6(3.6 .1) ; 3.8 \\
(3.8 .1 ; 3.8 .2) ; 11.2(11.2 .1) ; 11.6\end{array}$ & $\begin{array}{l}\text { To improve access to social protection and } \\
\text { health systems and services } \\
\text { To promote reductions in alcohol intake } \\
\text { To improve the efficiency of public transport } \\
\text { To promote safe walking, cycling, use of } \\
\text { public transport } \\
\text { To improve urban planning and road safety } \\
\text { (eg, use of helmets, use of seat belts, } \\
\text { speed limits, bicycle lanes, pavements) }\end{array}$ & $\begin{array}{l}\text { Proportion of population who have access to social } \\
\text { protection and health services-for example, time/ } \\
\text { kilometres from home and social support for travel/ } \\
\text { access } \\
\text { Reduce the intake of alcohol and related deaths by } \\
\text { x\% } \\
\text { Proportion of population travelling by public } \\
\text { transport, cycling and walking, by kilometres/number } \\
\text { of journeys } \\
\text { Number of road traffic accidents, injuries and deaths } \\
\text { by age group } \\
\text { Mortality and morbidity attributed to road traffic } \\
\text { accidents }\end{array}$ \\
\hline
\end{tabular}


Global Health Governance (GHG) actors could be brought together with community, national and regional organisations to form a focused network around a specific set of SDGs or targets.

Finally, we argue that tables 1-3 together offer an integrating framework that should be applied to ensure other sectors serve as cross-cutting themes to underpin the 2030 Sustainable Development Agenda. While the expansion from 8 MDGs and 18 targets, to 17 SDGs and 169 targets, is seen as a daunting and potentially unmanageable agenda, the framework identifies common and mutually reinforcing actions across the new agenda. In this way, efforts move away from the discrete objectives and institutional mechanisms of sector-specific actions, towards 'integrated and indivisible' actions which are innovative and transformative.

\section{CONCLUSION}

In this paper, we argue that the implementation of the 2030 Sustainable Development Agenda requires an operational approach to implementation that emphasises integration across the agreed goals and targets. We provide a framework for how health and well-being, as the focus of SDG 3, but also a major cross-cutting theme, as part of a health in all policies approach, ${ }^{22}$ can be operationalised through health and non-health sector objectives, measures or indicators. Ensuring healthy lives and promoting well-being for all individuals and populations is central to achieving sustainable development. Sustainable development, in turn, is critical to achieving health and well-being. Recognising that all 17 SDGs are linked, connected and interdependent is vital for achieving the SDGs, and now require translating into policy and practice. The framework put forth in this paper sets out a strategy for connecting the health and non-health sectors, closely linking goals and targets for addressing the social, economic, environmental and health determinants and outcomes of sustainable development over the next 15 years.

The proposed health and well-being framework put forward here provides a model for more integrated implementation of the SDGs. The approach complements the HiAP approach, by ensuring that health and well-being are cross-cutting and unifying themes. Importantly, the framework can also be used by other sectors to set particular objectives, measures or indicators which support an integrated approach to implementing the three dimensions of sustainable development which underpin the 2030 Agenda for Sustainable Development. There is nothing special about the themes of health and well-being in this respect. Other overarching sustainability themes could benefit from similar approaches.

\section{Handling editor Douglas Noble}

Contributors ARN conceived this article and wrote the first draft with contributions from TO. KL contributed substantially to the revised version of the paper. All authors contributed to the literature review and data interpretation, reviewed successive drafts, and approved the final version of the article.

Competing interests None declared.

Provenance and peer review Not commissioned; externally peer reviewed.

Data sharing statement No additional data are available.

Open Access This is an Open Access article distributed in accordance with the Creative Commons Attribution Non Commercial (CC BY-NC 4.0) license, which permits others to distribute, remix, adapt, build upon this work noncommercially, and license their derivative works on different terms, provided the original work is properly cited and the use is non-commercial. See: http:// creativecommons.org/licenses/by-nc/4.0/

\section{REFERENCES}

1. Osborn D, Cutter A, Ullah F. Universal Sustainable Development Goals. Understanding the Transformational Challenge for Developed Countries. Report of a study by Stakeholder Forum. Stakeholder Forum. 1-25 May 2015. https://sustainabledevelopment.un.org/ content/documents/1684SF_-_SDG_Universality_Report_-_May_ 2015.pdf (cited 2 August 2016).

2. United Nations. Transforming our world: the 2030 Agenda for Sustainable Development. 18 September 2015; 1-35. http:/www.un.org/ga/search/ view_doc.asp?symbol=A/70/L.1\&Lang=E (cited 2 August 2016).

3. United Nations Development Programme. A new sustainable development agenda. 2015. http://www.undp.org/content/undp/en/ home/mdgoverview.html (cited 2 August 2016).

4. United Nations Development Programme. Sustainable Development Goals (SDGs). 2015. http://www.undp.org/content/undp/en/home/ mdgoverview/post-2015-development-agenda/ (cited 2 August 2016)

5. World Health Organization (2015d). Health in 2015 from MDGs to SDGs. http://apps.who.int/iris/bitstream/10665/200009/1/ 9789241565110 eng.pdf?ua=1 (cited 2 August 2016).

6. Le Blanc D. Towards integration at last? The sustainable development goals as a network of targets. Sustainable Dev 2015;23:176-87.

7. Davis A, Matthews Z, Szabo S, et al. Measuring the SDGs: a two-track solution. Lancet 2015;386:221-2.

8. Yamey G, Shretta R, Binka FN. The 2030 sustainable development goal for health-must balance bold aspiration with technical feasibility. BMJ 2014;349:95295.

9. Hill PS, Buse K, Brolan CE, et al. How can health remain central post-2015 in a sustainable development paradigm? Global Health 2014;10:18.

10. World Health Organization. Positioning Health in the Post-2015 Development Agenda. WHO discussion paper. 1-4 October 2012. http://www.who.int/topics/millennium_development_goals/post2015/ WHOdiscussionpaper_October2012.pdf?ua=1 (cited 2 August 2016).

11. World Health Organization. Health promotion glossary. WHO/HPR/ HEP/98.1. Geneva: World Health Organization, 1998:1-36. http:/ www.who.int/healthpromotion/about/HPR\%20Glossary\%201998. pdf ?ua $=1$ (cited 2 August 2016)

12. Wilkinson R, Hulme D. The Millennium Development Goals and beyond - global development after 2015. Routledge. Global Institutions, 2012

13. United Nations. The Millennium Development Goals Report 2015. New York, 2015:1-75. http://www.un.org/millenniumgoals/2015 MDG_Report/pdf/MDG\%202015\%20rev\%20(July\%201).pdf (cited 2 August 2016)

14. O'Riordan T. Sustainability beyond austerity: possibilities for a successful transition to a well-being society. Análise Social 2014;211, XLIX $\left(2^{\circ}\right): 1-25$

15. Fehling M, Nelson BD, Venkatapuram S. Limitations of the Millennium Development Goals: a literature review. Global Public Health 2013;8:1109-22. http://www.ncbi.nlm.nih.gov/pmc/articles/ PMC3877943/ (cited 2 August 2016).

16. OECD. Is this humanitarian migration crisis different? Migration Policy Debates 2015;7:1-15. https://www.oecd.org/migration/ Is-this-refugee-crisis-different.pdf (cited 2 August 2016).

17. World Health Organization. From MDGs to SDGs: a new era for global public health 2016-2030. 2015:1-2. http://www.who.int/ mediacentre/events/meetings/2015/MDGs-SDGs-Summary.pdf? ua $=1$ (cited 2 August 2016).

18. New Security Beat. A reset for international development? UN debates what to include in Sustainable Development Goals. 2014. https://www.newsecuritybeat.org/2014/11/whats-internationaldevelopment-debates-include-sustainable-development-goals/ (cited 2 August 2016). 
19. Dora C, Haines A, Balbus J, et al. Indicators linking health and sustainability in the post-2015 development agenda. Lancet 2015;385:380-91.

20. World Health Organization. Preamble to the Constitution of the World Health Organization as adopted by the International Health Conference; 19-22 June, 1946, New York: signed on 22 July 1946 by the representatives of 61 States (Official Records of the World Health Organization, no. 2, p. 100) and entered into force on 7 April 1948. 1948

21. Borowy I. Sustainable health: the need for new developmental models. Bull World Health Organ 2014;92:699.

22. UNAIDS, UNICEF, UNFPA, WHO. Health in the post-2015 UN development agenda. Thematic Think Piece. UN System Task Team on the Post-2015 UN Development Agenda. 1-17 May 2012. http:// www.who.int/topics/millennium development goals/post2015/ post2015_UNdevelopment_agenda_think_20120918.pdf?ua=1 (cited 2 August 2016).

23. Centers for Disease Control and Prevention. Well-being Concepts. 2013. http://www.cdc.gov/hrqol/wellbeing.htm (cited 2 August 2016).

24. United Nations Development Programme. Rio Declaration on Environment and Development. The United Nations Conference on Environment and Development. 3-14 June 1992. http://www.unep. org/Documents.Multilingual/Default.asp?

documentid=78\&articleid=1163 (cited 2 August 2016).

25. Kickbusch I. A game change in global health: the best is yet to come. Public Health Rev 2013;35:1.

26. World Health Organization. Health in the Post-2015 Development Agenda. Briefing Paper 1. 1-2 September 2012. http://www.who.int/ topics/millennium_development_goals/post2015/healthinthepost briefing 20120921.pdf?ua=1 (cited 2 August 2016)

27. Murray C. Choosing indicators for the health-related SDG targets. Lancet 2015;386:1314-17.

28. World Health Organization. UN Sustainable Development Summit 2015. 25-27 September 2015. http://www.who.int/mediacentre/ events/meetings/2015/un-sustainable-development-summit/en/ (cited 2 August 2016)

29. United Nations. Compilation of metadata for the proposed global indicators for the review of the 2030 agenda for sustainable development. Department of Economic and Social Affairs, United Nations Statistics Division, 4 March 2016. http://unstats.un.org/sdgs/ iaeg-sdgs/metadata-compilation/ (cited 2 August 2016).

30. World Health Organization. Health in the post-2015 development agenda. SEA/RC68/27. 2015. http://apps.who.int/iris/handle/10665/ 180807 (cited 2 August 2016).

31. Griggs D, Stafford SM, Rockstrom J, et al. An integrated framework for sustainable development goals. Ecol Soc 2014;19:4

32. Griggs D, Stafford-Smith M, Gaffney O, et al. Policy: sustainable development goals for people and planet. Nature 2013:495:305-7.

33. Leppo K, Ollila E, Pena S, et al. Health in all policies: seizing opportunities, implementing policies. Helsinki: Ministry of Socia Affairs and Health, Finland, 2013:1-358. http://www.euro.who.int/ data/assets/pdf_file/0007/188809/Health-in-All-Policies-final.pdf (cited 2 August 2016)

34. Becerra-Posada F. Health in all policies: a strategy to support the Sustainable Development Goals. Lancet Glob Health 2015;3:e360. 